\title{
Obituaries
}

Obituaries should be submitted by email to Ruth Doherty at r.doherty@nature.com.

All submitted obituaries should be 450 words maximum in length (apart from obituaries for past presidents of the BDA where the length should be 800 words).

Content of the obituary is down to the individual author, and the approval of the family should be given for the obituary prior to submission to the BDJ

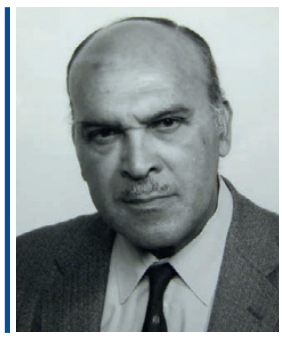

Athiel Lushington

King

1923-2015

Athiel King was born on the 4 January 1923, in Barbados, West Indies, the son of a shopkeeper, Edwin King and Alice Gaskin, his mother, who died when he was two years old. He was one of four children. His early adult years were spent as a school teacher before he left for the United Kingdom at the age of 20 , journeying by ship to Liverpool to join the Royal Air Force as a radar technician. He served at various bases in the South West of England, until the end of World War II. During his time in the RAF, at a service at St Pauls Cathedral, he met his future wife, Ruth, who had come to the UK from Tobago in the West Indies to study midwifery. They eventually married in May 1950.

After leaving the RAF, Athiel worked in the civil service and local government for several years. He used his spare time to study for A-levels, as he was determined to study dentistry. After a number of disappointments, he finally received his chance when he was offered a place at University College Hospital, London by the late Professor Prophet in 1964, at the mature age of 41 . He excelled at his studies, and won the year medal awarded to the best student in conservative dentistry.

After gaining his LDS and BDS, Athiel worked a number of sessional dental posts, until establishing a dental practice, in Balham, in South London. In 1970, Athiel started a dental practice in the family home in Wallington, Surrey where he lived and continued to practice for the next thirty years. Athiel returned to University College Hospital in 1980 as a part-time clinical demonstrator in the restorative department, where he enjoyed sharing his practical skills and teaching dental students.

Athiel had a passion for West Indies cricket, a fondness for Country Life magazine and motor racing and an enduring devotion to Jaguar cars - his first, a Mark IX, bought in 1967. He died in Musgrove Park Hospital, Taunton, Somerset on the 6 October 2015, aged 92, after a short illness. Having lost his wife, Ruth, after forty-five years of marriage in 1995, Athiel is survived by his sons, Philip and Adrian, grand-daughters, Monica and Hannah, and great grand-daughter, Chloe.

Athiel will be greatly missed by his friends and family and by the many patients who travelled many miles to see him, even after he moved his practice. He loved his profession, and always remained grateful to those who gave him the opportunity to join it, and he remained a member of the British Dental Association until the final year of his life.

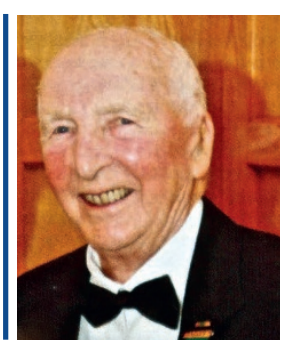

\section{Brian Morrison Tweedie}

1923-2016

Brian was brought up on Skegoneill Avenue in North Belfast. He attended the local primary school and went on to RBAI (Royal Belfast Academical Institution), where he played in the 1942 Schools' Cup Rugby Final. During the second world war, Brian's family were evacuated to Rathfriland where he had many cherished memories of living with the Fegan family.
On leaving school, Brian joined the Northern Bank and was posted to Irvinestown. In 1943 he joined the Royal Navy and served on three landing ships, HMS Princess Astrid, HMS Eastway, and HMS Boxer.

Brian told the story of how his ship picked up a German U-Boat on radar, which they successfully torpedoed only to discover they had torpedoed a whale!

Brian was demobbed in 1946 and commenced his studies for dentistry at Queens University Belfast. Unfortunately, Brian contracted tuberculosis in the Navy and spent two years in hospital, qualifying from Queens in 1953.

Brian set up a very successful practice in Rathcoole and became a very active member of the Northern Ireland branch of the BDA. Brian served as Secretary, Branch President (1983) and was Trustee of the Benevolent Fund for many years serving on the Executive Committee.

Brian was elected to the International College of Dentists for services to dentistry, was awarded Life Membership of BDA in 1990 and was elected a Fellow of the BDA in 1998. He was involved in the establishment of a general practice training unit in the School of Dentistry and worked part-time in a teaching post there.

Brain was a very keen golfer and an active member of Greenisland Golf Club where he was Captain in 1969 and was President for the club's centenary year - 1994 .

Brian was a longstanding member of St. Peter's Parish Church where he served in many capacities. Brian, with his Navy background was called on every year to lay a wreath on Remembrance Sunday.

Brian is survived by his wife (of nearly 60 years), Heather, son, Philip and daughters, Jenny, Caroline and Susie.

P. S. D. Henderson 